\title{
Examination of the Relationships Between Mathematics Literacy Self-Efficacy Perceptions of Preschool Teachers and Geometric Shape Recognition and Number Skills of Children With Structural Equation Modelling
}

\author{
Özgün Uyanık Aktulun ${ }^{1}$ \\ ${ }^{1}$ Faculty of Education, Afyon Kocatepe University, Afyon, Turkey \\ Correspondence: Özgün Uyanık Aktulun, Faculty of Education, Department of Early Childhood Education, Afyon \\ Kocatepe University, Afyon, Turkey. Tel: 90-272-228-1326. E-mail: ozgunuyanik@hotmail.com
}

Received: August 4, 2018

Accepted: September 18, 2018

Online Published: November 27, 2018

doi:10.5539/ies.v11n12p63

URL: https://doi.org/10.5539/ies.v11n12p63

\begin{abstract}
This study aimed to examine the relationship of mathematics literacy self-efficacy perceptions of preschool teachers with geometric shape recognition and number skills of children using structural equation modelling. The descriptive study adopted a relational screening model. The study sample comprised 9 teachers and 103 children selected by maximum variation sampling in the Afyon province. The Self-Efficacy Scale for Mathematics Literacy developed by Özgen and Bindak (2008), the Geometric Shape Recognition Test developed by Aslan (2004) and the K-SEALS used by Uyanık and Kandır (2014) for validity and reliability studies were employed in the study. The relationships between the study variables were examined with structural equation modelling. The study results showed that teachers' level of mathematical literacy self-efficacy was an important predictor of children's recognition of geometric shapes and their numerical skills.
\end{abstract}

Keywords: mathematics literacy self-efficacy, geometric shape recognition, number skills, preschool teachers, preschool education

\section{Introduction}

Due to the contemporary need for mathematically literate individuals who can use their mathematical knowledge and skills in their daily lives, emphasis is placed on laying the foundation for the acquisition of mathematical skills from the preschool period (Anders, Grosse, Rossbach, Ebert, \& Weinert, 2013; Anders \& Rossbach, 2015; Çelik, 2014). In the preschool period, children are exposed to many mathematical concepts and skills in the course their daily life (i.e. in their games, stories, routine activities, singing, conversations, social relationships, etc.), during which they can experience and acquire skills like mathematical concepts, recognition, naming, matching, comparing, grouping, sorting, numbers, operations, modelling, geometry, spatial-logic (spatial perception), measurement and graphing. As teachers can relate mathematics to real life, children are more interested and motivated towards mathematics and more inclined to participate in learning activities (Charlesworth \& Lind, 2007; Smith, 2009). Therefore, the Program for International Student Assessment (PISA) by the Organization for Economic Cooperation and Development (OECD) highlights the topic of "mathematical literacy" in realistic practices associated with everyday life in mathematics education in order to raise the quality of education. OECD (2003) defines mathematical literacy as "An individual's capacity to identify and understand the role that mathematics plays in the world, to make well-founded judgments and to use and engage with mathematics in ways that meet the needs of that individual's life as a constructive, concerned and reflective citizen (p.15)". Mathematical literacy is considered, in the first dimension, as the content of the mathematics field in the first dimension (i.e. quantity, space-shape, change-relation, uncertainty), as mathematical processes defined by general mathematical competencies in the second dimension (i.e. thinking-reasoning, proof, communication, modelling, problem posing and solving, representing, using symbols, formal and technical languages and operations, using tools) and as the situations where mathematics is used in social, current and scientific events in the third dimension (OECD, 2003, p. 30). Mathematical literacy requires listening, speaking, reading, communicating and writing to understand the symbols, the concepts and the terminology of mathematics, rather than to understand mathematical ideas (Thompson \& Chappbell, 2007). The literature 
indicates that the foundation for mathematical literacy is laid in the preschool period (NCTM, 2000), that teachers with a high level of mathematical literacy promote the development of mathematical knowledge, competencies and literacy skills in children (Akkaya \& Sezgin-Memnun, 2012; Rittenhouse, 1998) and that it can also act on children's mathematical achievement (Gellert, Jablonka, \& Keitel, 2001). However, positive attitudes and affective behaviors of individuals towards mathematical values and beliefs as well as studying mathematics are also fall within the scope of mathematical literacy (Yore, Pimm, \& Tuan, 2007). Self-efficacy, i.e. one's judgment of and belief in oneself which influences one's behavior, can be regarded as one of the important factors in the development of mathematical literacy (Özgen \& Bindak, 2011).

In current research in the field of education, teachers' self-efficacy in various topics and studies on its effects have gained prominence. The mathematical literacy self-efficacy belief discussed within the scope of this study is "the belief and judgment of one's own abilities in mathematical processes, skills and situations that an individual has encountered in school, work and everyday life" (Özgen \& Bindak, 2011). As the mathematics literacy self-efficacy of teachers is an important motivational tool that increases their productivity in the classroom, it can affect children's acquisition of mathematical skills (Özgen \& Bindak, 2011). Because self-efficacy perception plays a role in the behavior of individuals (Bandura, 1993), teachers' behaviors (Czerniak \& Chiarelott, 1990) can change the level of their efforts, goals and enthusiasm in class activities (Tschannen-Moran \& Woolfolk-Hoy, 2001) by acting on variables such as skills, ability and knowledge (Pajares \& Miller, 1994). Gellert (2004) indicated the relationship of mathematical literacy with material use and teaching methods during mathematics teaching. Teachers with high mathematical literacy self-efficacy can figure out ways to increase the quality of teaching, promote desirable behaviors and create a more efficient learning environment in order to improve the quality of education. In addition, teachers with high mathematics literacy self-efficacy can engage in efforts for self-improvement during the teaching-learning process. This would allow teachers to encourage children to listen, speak, read and write mathematical concepts, and contribute to communication and representation in the development of mathematical literacy in children (Thompson \& Chappbell, 2007). In addition, teachers' attitudes towards mathematics and their perceptions of self-efficacy can also affect children's interest, motivation and achievement in mathematics (Caprara, Barbaranelli, Steca, \& Malone 2006; Thornton, Crim \& Hawkins, 2009). Teachers with high mathematics self-efficacy involve children in the learning process through various methods and strategies (Cousins \& Walker, 1995 Guskey, 1998 as cited in Caprara et al., 2006), plan and implement a more entertaining mathematics education (Stipek, Givvin, Salmon, \& MacGyvers 2001), combat problems and provide constructive feedback (Gibson \& Dembo, 1984), which can lead to positive effects on children's mathematical achievements.

There was an increase in research on mathematical literacy with the realization of its importance, but the studies were lacking in terms of both variety of research methods and examination by different levels of education. Notwithstanding the existence of research indicating the direct correlation of teacher self-efficacy with class quality and student achievement, the number of studies conducted with preschool teachers and preschoolers were quite limited. The researchers did not find any studies indicating that preschool teachers' mathematical literacy self-efficacy predicted children's numbers and geometry skills. In the PISA exams through 2003-2012, children participating from Turkey received the lowest score in geometry (shape and space) after arithmetic (Zopluoğlu, 2014). Therefore, considering the importance assigned to field knowledge within the scope of OECD mathematics literacy and the fact that the mathematical skills acquired in the preschool period affects childrens' mathematical achievement for life (Denton \& West, 2002), studies that show the direct correlation of mathematics literacy self-efficacy perceptions of preschool teachers with children's number and geometry skill development have the potential to be the focus of attention. In PISA studies, mathematical skills related to mathematical literacy such as mathematically formulating situations, using mathematical concepts and operations, reasoning and interpretation of mathematical output, application and evaluation are examined and reported, with a particular emphasis on mathematical literacy. Therefore, mathematical literacy has become one of the most important subjects in the educational reforms of countries and research on mathematical literacy has gained prominence. The lack of direct studies on mathematical literacy self-efficacy of preschool teachers and children's geometric shape recognition and number skills, a subject of significant prominence throughout the world, further increases the importance of this study, which the researchers believe would provide guidance to future studies. From this perspective, the study aimed to investigate the relationship of preschool teachers' mathematical literacy self-efficacy perceptions with children's geometrical shape recognition and numerical skills using structural equality modelling.

The researchers sought the answers to the following questions:

Do mathematics literacy self-efficacy levels of preschool teachers predict children's ability to recognize 
geometric shapes?

Do mathematics literacy self-efficacy levels of preschool teachers predict children's numerical skills?

\section{Method}

This section provides explanations on the type of research, sampling, data collection tools, procedures and data analysis.

\subsection{Research Type}

This relational study has examined the relationship between mathematical literacy self-efficacy levels of preschool teachers and the recognition of geometric shapes and numeric skills of children aged 60-72 months. Relational screening models are research models aiming to determine the presence or degree of change of co-existence between two or more variables (Cohen, Manion, \& Morrison, 2000, Sönmez \& Alacapınar, 2013).

In the study, a model of structural equality was established to provide a clearer picture of the relationship between variables (Brown, 2006). The structural equation modelling is a statistical technique used in testing within the context of a relationship between measured and latent variables. It is the general name given to the techniques that allow examination through variables whose latent structures are observed (Jöroskog \& Sörbom, 1993). The structural equation modelling combines the predictive structural relationship between the variables in the regression model and the latent factor structures in factor analysis into one comprehensive analysis (Çokluk, Şekercioğlu, \& Büyüköztürk, 2010). In this respect, this study also reveals the degree of the associations between the variables.

\subsection{Study Population and Sampling}

The study population has comprised teachers and children aged between five and six years attending preschool in Afyonkarahisar during the 2016-2017 school year. Maximum variation sampling, a purposive sampling method, was adopted in sample selection. In this context, in view of the ability of the sample to represent the population, the researchers have attempted to select teachers and children in schools from upper, middle and lower socioeconomic classes (McMillan \& Schumacher, 2006). This type of sampling method will provide important clues about the population values as different situations related to the problem are taken to the sample (Yıldırım \& Şimşek, 2016). 103 normally developing children and 9 teachers from the designated schools have been included in the study on the basis of voluntary participation.

$33.3 \%$ and $66.7 \%$ of the teachers in the sample group were $25-29$ and 30-39 years old, respectively. All the teachers had undergraduate degrees. $56.3 \%$ of the children in the sample group were female, while $43.7 \%$ were male.

\subsection{Data Collection Tools}

The following data collection tools were employed in line with the study objective.

\subsubsection{Teacher Demographic Information Form}

In the study, the Teacher Demographic Information Form, which was completed by the teachers, has been used to gather information about their age and educational status.

\subsubsection{Child Demographic Information Form}

The Child Demographic Information Form involved the date of birth and gender of the children. The form has been completed by the researchers for each child according to the information in their personal development files at the school.

\subsubsection{Self-Efficacy Scale for Mathematics Literacy}

The Self-Efficacy Scale for Mathematics Literacy was developed by Özgen and Bindak (2008) to measure self-efficacy beliefs for mathematics literacy of teacher candidates. It is a five-point Likert-type measure consisting of a total of 25 items with 4 negative items. Positive items on the scale are scored from 5 to 1 towards as "Totally Agree" and "Totally Disagree" while negative items are scored from 1 to 5 . The lowest possible score on the scale is 25 and the highest possible score is 175. A high score from the scale indicates high mathematical literacy self-efficacy for teacher candidates. Factor analysis has showed that the only factor of the scale explained $42.85 \%$ of the variance. In addition, the item-total score correlations have ranged from 0.48 to 0.75 and the Cronbach alpha reliability coefficient has been 0.94 (Özgen \& Bindak, 2008). As the validity and reliability studies of the scale have been conducted with teacher candidates, the validity and reliability analyses have been renewed with the data collected from 157 preschool teachers selected by random sampling to be used in the present study, after obtaining the necessary permissions from the Provincial Directorate of National 
Education. In this context, the Cronbach alpha coefficient has been initially computed in order to both determine the applicability of the Self-Efficacy Scale for Mathematics Literacy developed by Özgen and Bindak (2008) for teachers and expand the range and to confirm the statistical reliability and validity of the results. The reliability coefficient values for each item of the scale with 25 items and one subscale are shown in Table 1.

Table 1. Self-efficacy scale for mathematics literacy reliability analysis results

\begin{tabular}{|c|c|c|c|c|}
\hline & $\begin{array}{c}\text { Scale average when item is } \\
\text { deleted }\end{array}$ & Item-scale correlation value & $\begin{array}{l}\text { Square of the multiple } \\
\text { correlation coefficient }\end{array}$ & $\begin{array}{c}\text { Correlation coefficient when } \\
\text { item is deleted } \\
\end{array}$ \\
\hline item 1 & 88.8408 & .693 & .676 & .928 \\
\hline item 2 & 88.8025 & .777 & .758 & .926 \\
\hline item 3 & 88.6178 & .708 & .689 & .928 \\
\hline item 4 & 88.7834 & .711 & .709 & .927 \\
\hline item 5 & 88.6624 & .548 & .560 & .930 \\
\hline item 6 & 89.0510 & .277 & .483 & .935 \\
\hline item 7 & 88.2803 & .569 & .579 & .930 \\
\hline item 8 & 88.3312 & .434 & .428 & .931 \\
\hline item 9 & 88.8344 & .327 & .583 & .933 \\
\hline item 10 & 88.7580 & .432 & .364 & .931 \\
\hline item 11 & 88.6051 & .647 & .616 & .928 \\
\hline item 12 & 88.4841 & .747 & .730 & .927 \\
\hline item 13 & 88.7134 & .747 & .664 & .927 \\
\hline item 14 & 88.5350 & .642 & .652 & .929 \\
\hline item 15 & 88.5732 & .626 & .734 & .929 \\
\hline item 16 & 88.7643 & .711 & .697 & .927 \\
\hline item 17 & 88.8854 & .766 & .735 & .926 \\
\hline item 18 & 89.0064 & .255 & .337 & .935 \\
\hline item 19 & 88.4650 & .428 & .431 & .931 \\
\hline item 20 & 88.7006 & .734 & .675 & .927 \\
\hline item 21 & 88.8408 & .681 & .617 & .928 \\
\hline item 22 & 88.8344 & .407 & .475 & .932 \\
\hline item 23 & 88,6306 & .629 & .571 & .929 \\
\hline item 24 & 88,3885 & .524 & .758 & .930 \\
\hline item 25 & 88.4777 & .570 & .772 & .930 \\
\hline
\end{tabular}

Examination of Table 1 has revealed that the reliability of the 25 -item scale is 0.93 and the corrected alpha value is 0.94 . The alpha value does not exceed 0.93 when any of the items are deleted and the item-scale correlation values are above 0.30 (i.e. the cut-off point), which indicate that the results obtained from the administration of the Self-Efficacy Scale for Mathematics Literacy to teachers are reliable.

Following this procedure, a first-order confirmatory factor analysis is performed in the LISREL program to provide evidence of the validity of the scale. Although the factor loadings are 0.40 and the $t$ values are 1.96 in the measurement model, it is decided to examine the modification indices first as $\chi^{2} / d f$, one of the most important indices for model-data fit, is found to be 3.74. In view of the amendments proposed by the program, it is decided to combine the error terms for the items due to the one-dimensional structure of the scale (Kline, 2011). Having examined the correction indices suggested by Lisrel software, the error values for the first three items are correlated, it is reported that chi-square values will be decreased as follows; 89.90 for $24^{\text {th }}$ and $25^{\text {th }}$ items, later 44.30 for $6^{\text {th }}$ and $9^{\text {th }}$ items and lastly 37.00 for $1^{\text {st }}$ and $2^{\text {nd }}$ items. The measurement model obtained with the implementation of the modification suggestions is given in Figure 1. 


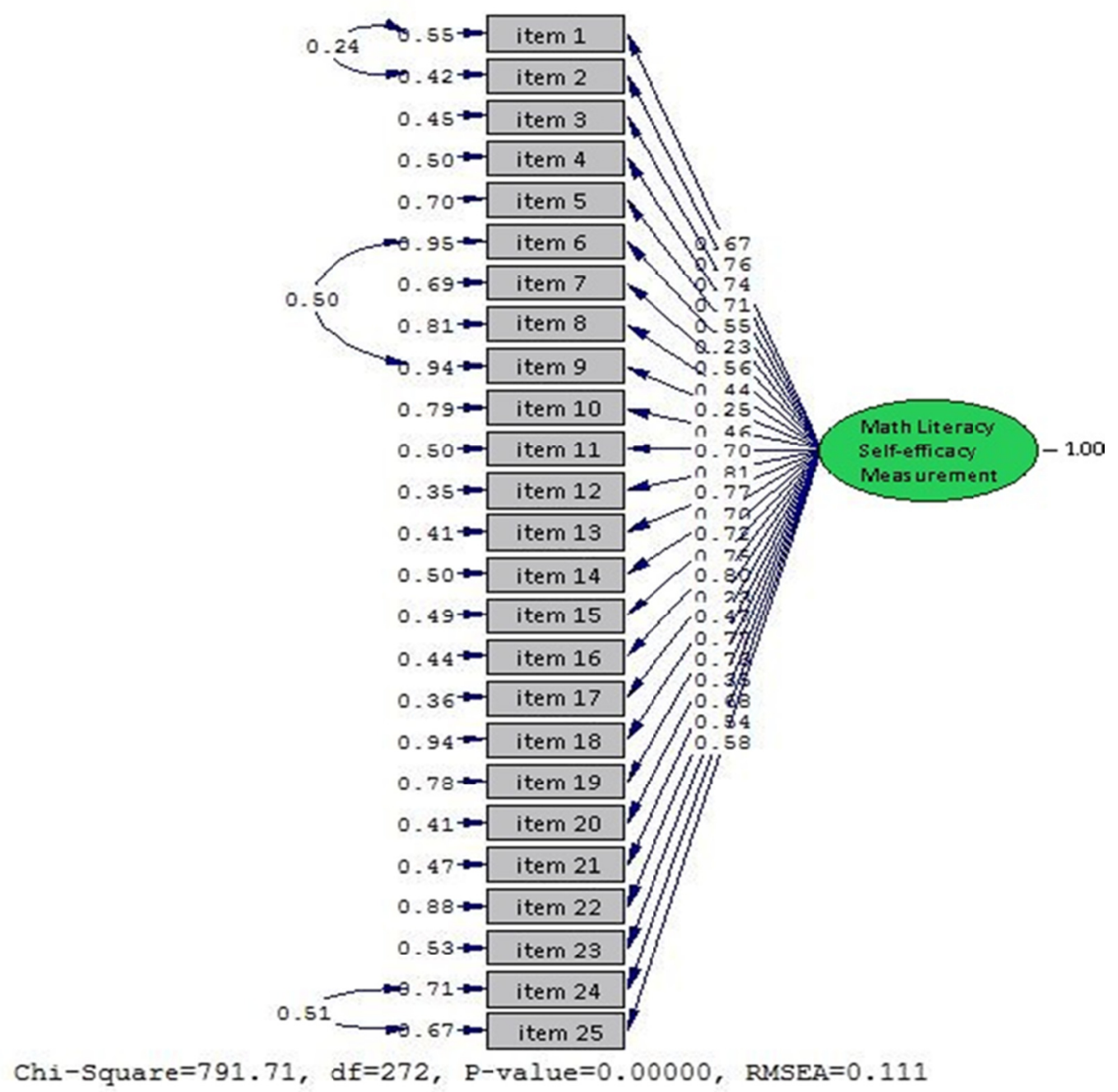

Figure 1. Standardized loadings for the second model installed after modification suggestions

Figure 1 shows that the chi-square value decreases from 1029.76 to 791.71 . In addition, the degree of freedom decreases from 275 to 272 with 3 correlated error terms. $\chi^{2} / d f$ ratio is calculated as $2.90(791.71 / 272)$. The results indicate that the model is acceptable (Marsh \& Hocevar, 1985). Table 2 shows the goodness-of-fit results for the measurement model obtained with DFA.

Table 2. DFA results for the one-dimensional measurement model

\begin{tabular}{lccccccc}
\hline Model & $\chi^{2}$ & $\chi^{2} / \mathrm{sd}$ & NFI & GFI & NNFI & CFI & RMSEA \\
\hline Single Factor Structure & 791.71 & 2.90 & .90 & .87 & .92 & .94 & .111 \\
Measures & & $\leq 3$ & $\geq .90$ & $\geq .85$ & $\geq .90$ & $\geq .95$ & $\leq .08$ \\
\hline
\end{tabular}

NFI: Normed Fit Index, NNFI: Non-normed Fit Index, GFI: Goodness of Fit Index, CFI: Comparative Fit Index, RMSEA: Root Mean Square Error of Approximation.

The DFA results given in Table 2 show that all fit indices are acceptable and that the one-dimensional model of the materials in the scale is appropriate (Bentler, 1990; Kline, 2011). 


\subsubsection{Geometric Shape Recognition Test}

The "Geometric Shape Recognition Test" which has been developed and whose validity and reliability study has been conducted by Aslan (2004) is composed of 4 subscales, namely triangle, square, circle and rectangle. In the triangle recognition test, there are 12 items, 7 triangles and 5 distractors. There are 12 items in the rectangle recognition test, 5 rectangles and 7 distractors. There are 12 items in the square recognition test, 4 squares and 8 distractors. Finally, the circle recognition test comprises 12 items, including 5 circles and 7 distractors. Each subscale is on a separate sheet of A4 paper and has a total of 48 items. In the test, 1 point is awarded for each correct answer and 0 points for each incorrectly answer. The minimum and maximum possible test scores are 0 and 48, respectively. Investigation of the discrimination index of each item reveals that there is no item below 0.15 and item discrimination power ranges between 0.32 and 0.99 . In the test, KR-20 alpha values are determined as 0.80 for the triangle recognition test, 0.88 for the rectangular recognition test, 0.81 for the square recognition test, and 0.77 for the circle recognition test (Aslan, 2004; Aslan \& Aktaş-Arnas, 2007). KR-20 reliability value for the overall test is computed as 0.824 .

\subsubsection{Number Skills Scale}

The Number Skills Scale is a subscale of the Kaufman Survey of Early Academic and Language Skills developed by Kaufman and Kaufman (1993), which evaluates early language, cognitive competencies and academic skills of children aged between 36-83 months. In the Number Skills Scale, the child identifies numbers, counts, shows knowledge of numerical concepts and solves numerical problems. The scale consists of 17 items. One (1) score is recorded on the test registration form for each correct answer and zero (0) points is recorded for each incorrect answer. The raw score for the scale is the number of items correctly answered (Kaufman \& Kaufman, 1993). Confirmatory factor analysis results for the Number Skills Scale adapted into Turkish by Uyanık and Kandır (2014) confirmed the one-dimensional factor structure. KR-20 reliability coefficient of the Number Skills Scale is computed as 0.957 and the item total correlation coefficient is found to be highly reliable. The test retest correlation for the Number Skills Scale is found to be 0.799. KR-20 reliability value for the overall test is calculated as 0.883 .

\subsection{Data Collection}

Prior to data collection, the necessary permits have been firstly obtained from the Afyon Provincial Directorate of National Education. Then, the teachers in the sample group and the parents of the children have been informed about the purpose of the study. They have been informed that the data about the participant shall only be used for the purpose of this study and shall not be shared with any other institution or person. Once more, the participants have been instructed prior to administration that it was not compulsory to participate in the study, ensuring the study group consisted only of voluntary participants. The participants have also been requested to provide honest replies, so that valid and reliable results could be obtained. In the first part of the data collection tool, information about the participants' demographics has been filled out by the teachers from the children's files. In the selected schools, 9 volunteer teachers have been asked to complete the Self-Efficacy Scale for Mathematics Literacy. After selecting an equal number of children from the classes of each volunteer teacher, the "Geometric Shape Recognition Test" and the "Numerical Scale" have been administered to the children by the researchers on two separate days. The administration of the test and the scale at the schools has been carried out in a quiet room separate from educational environments, on a table and chairs suitable for children to help the children concentrate and provide motivation. The children have been taken one by one to a room set up in advance. The children have briefly been informed about the administration after a short conversation aimed to help the children to relax. The administration of the scale has started with sample questions so that the child could learn about the scale. During administration, the information given about the administration has been repeated until the child has indicated that he/she understood what was asked of him/her.

\subsection{Data Analysis}

The study data were analyzed so as to provide answers to the sub problems. In the study, the relationship between mathematics literacy self-efficacy of preschool teachers and the recognition of geometric shapes and number skills of 60-72-month-old children were examined with the Pearson Product-Moment Correlation Coefficient, and the predictive effect of teachers' mathematical literacy self-efficacy levels on children's geometry and numerical skills were investigated with path analysis, a structural equation model. In the analyses, teachers' mathematical literacy self-efficacy scores were regarded as external variables, while the children's recognition of geometric shapes and numerical skills scores were regarded as internal variables (Cheng, 2001; Jöreskog \& Sorbom, 1993). By using the structural equation model, the variables and the relationships between the variables were identified and how much the proposed relational pattern fits the actual data was determined. 
In the structural equation model, various modification indices are used to decide whether the model predicted by the researcher is verified by the collected data. In the study, fit indices such as the Chi-Square Goodness test, the Goodness of Fit Index (GFI), the Adjustment Goodness of Fit Index (AGFI), the Comparative Fit Index (CFI), the Normed Fit Index (NFI), the Relative Fit Index (RFI), the Incremental Fit Index (IFI), the Root Mean Square Error of Approximation (RMSEA) and the Standardized Root Mean Square Residual (SRMR) were used to investigate the adequacy of the model that was constructed to identify the relationship between teachers' mathematical literacy self-efficacy and children's geometry and numerical skills,. There is no consensus among researchers as to what criteria should be taken into account for the compliance indices (Wetson \& Gore Jr, 2006). In general, for fit indices, 0.90 indicates are an acceptable fit for GFI, CFI, NFI, NNFI and IFI indices and a value of 0.95 indicates a perfect fit (Bentler \& Bonett, 1980). For AGFI, 0.85 means an acceptable fit and 0.90 means an excellent fit (Schermelleh-Engel, Moosbrugger, \& Müller, 2003). For RMSEA, 0.08 values are considered as acceptable fit and 0.05 values are taken as perfect fit standards (Byrne \& Campbell, 1999). For SRMR, 0.05 indicates excellent fit and 0.10 indicates acceptable fit (Kline, 2011).

\section{Results}

The correlation matrix comprising the correlation values for the observed variables are given in Table 3 .

Table 3. Correlation coefficients for study variables

\begin{tabular}{|c|c|c|c|c|c|c|c|}
\hline & & $\begin{array}{l}\text { Number } \\
\text { Skills } \\
\end{array}$ & $\begin{array}{l}\text { Geometric Shape } \\
\text { Recognition }\end{array}$ & $\begin{array}{l}\text { Math Literacy } \\
\text { Self-Efficacy }\end{array}$ & Triangle & Circle & Square \\
\hline \multirow{2}{*}{ Number Skills } & $\mathrm{r}$ & & & & & & \\
\hline & $\mathrm{p}$ & & & & & & \\
\hline \multirow{2}{*}{$\begin{array}{l}\text { Geometric } \\
\text { Recognition }\end{array}$} & $\mathrm{r}$ & $.528^{* *}$ & & & & & \\
\hline & $\mathrm{p}$ & .000 & & & & & \\
\hline \multirow{2}{*}{ Math Literacy Self-Efficacy } & $\mathrm{r}$ & $.735^{* *}$ & $.822^{* *}$ & & & & \\
\hline & $\mathrm{p}$ & .000 & .000 & & & & \\
\hline \multirow{2}{*}{ Triangle } & $\mathrm{r}$ & $.341^{* *}$ & $.732^{* *}$ & $.577^{* *}$ & & & \\
\hline & $\mathrm{p}$ & .000 & .000 & .000 & & & \\
\hline \multirow{2}{*}{ Circle } & $\mathrm{r}$ & $.298^{* *}$ & $.779^{* *}$ & $.608^{* *}$ & $.396^{* *}$ & & \\
\hline & $\mathrm{p}$ & .002 & .000 & .000 & .000 & & \\
\hline \multirow{2}{*}{ Square } & $\mathrm{r}$ & $.466^{* *}$ & $.824^{* *}$ & $.690^{* *}$ & $.406^{* *}$ & $.619^{* *}$ & \\
\hline & $\mathrm{p}$ & .000 & .000 & .000 & .000 & .000 & \\
\hline \multirow{2}{*}{ Rectangle } & $\mathrm{r}$ & $.548^{* *}$ & $.820^{* *}$ & $.715^{* *}$ & $.478^{* *}$ & $.484^{* *}$ & $.596^{* *}$ \\
\hline & $\mathrm{p}$ & .000 & .000 & .000 & .000 & .000 & .000 \\
\hline
\end{tabular}

** Correlation value was found to be significant at 0.01 level (double tailed).

Table 3 reveals statistically significant relationships between all the variables used in the model to be tested by the researcher. In addition, there is a statistically significant correlation between the mathematical literacy self-efficacy of preschool teachers and the ability of children to recognize geometric shapes tested in the first sub-objective of the study $(\mathrm{r}=0.82, \mathrm{p}<0.01)$ as well as between the mathematical literacy self-efficacy of preschool teachers and the children's numerical skills tested in the second sub- objective of the study $(r=0.74, p$ $<0.01$ ). As the results reveal statistically significant relationships between the observed variables, the theoretical model is tested to determine the effect of the level of mathematical literacy self-efficacy of preschool teachers on geometric shape recognition and numerical skills of their students. The analysis results are given in Figure 2. 


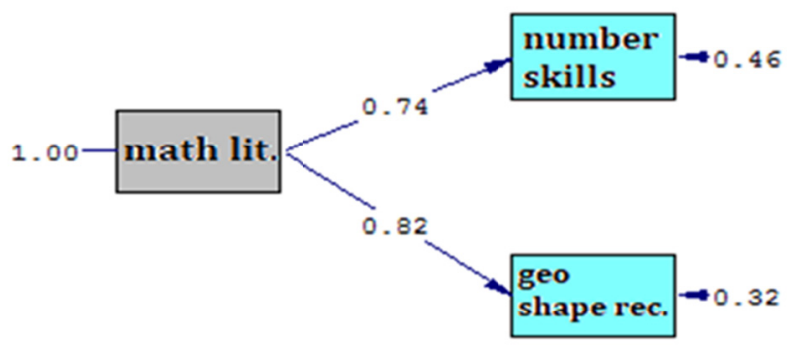

Chi-Square=4.04, df=1, P-value=0.04456, RMSEA=0.173

Figure 2. Standardized factor loadings for the tested theoretical model

In Figure 2, the mathematical literacy self-efficacy level of the teachers is significantly high for both geometric shape recognition $(\beta=0.82, \mathrm{t}=14.51)$ and numerical skills $(\beta=0.74, \mathrm{t}=10.91)(\mathrm{p}<0.05)$ according to the standardized regression coefficients. When assessed as a whole, the model is found to be significant $(p<0.05)$. However, the error value of the model is slightly above the critical level of 0.08 . The fit indices for the model are shown in Table 4.

Table 4. Goodness of fit results of the tested model

\begin{tabular}{lc}
\hline Model Fit Index & Results \\
\hline Chi-square value & 4.04 \\
P (Significance Level) & 0.044 \\
GFI (Goodness of Fit Index) & 0.970 \\
AGFI (Adjustment Goodness of Fit Index) & 0.850 \\
IFI (Incremental Fit Index) & 0.980 \\
CFI (Comparative Fit Index) & 0.980 \\
NFI (Normed Fit Index) & 0.970 \\
RFI (Relative Fit Index) & 0.920 \\
SRMR (Standardized Root Mean Square Residual) & 0.031 \\
\hline
\end{tabular}

In the obtained goodness of fit indices, the AGFI value ranges from 0 to 1 and an AGFI with a value more than 0.90 is taken as an excellent model indicator. CFI is also known as the Bentler Comparative Fit Index. It compares the compatibility of the current model with the coincidence between the hidden variables and the $\mathrm{H}_{0}$ hypothesis model, which ignores the covariance. The IFI value, also referred to as DELTA2, may be greater than 1 in some cases, in which case it is set at 1 . In general, an IFI value greater than 0.90 is desirable. NFI value; which is developed by Bentler and Bonett is a series of tests called normed fitness index. This index investigates the fitness of the hypothetical model with the basic or $\mathrm{H}_{0}$ hypothesis. The goal is to determine the amount of fitness that is improved by using the hypothetical model. Furthermore, the standardized error is computed as 0.031. The goodness of fit indices given in Table 4 indicates that the overall model has a high degree of fitness.

The regression equation after the adoption of the mathematical literacy self-efficacy levels of teachers as the independent variable and children's recognition of geometric shapes and numerical skills as dependent variables is presented in Figure 3. 
LISREL Estimates (Maximum Likelihood)

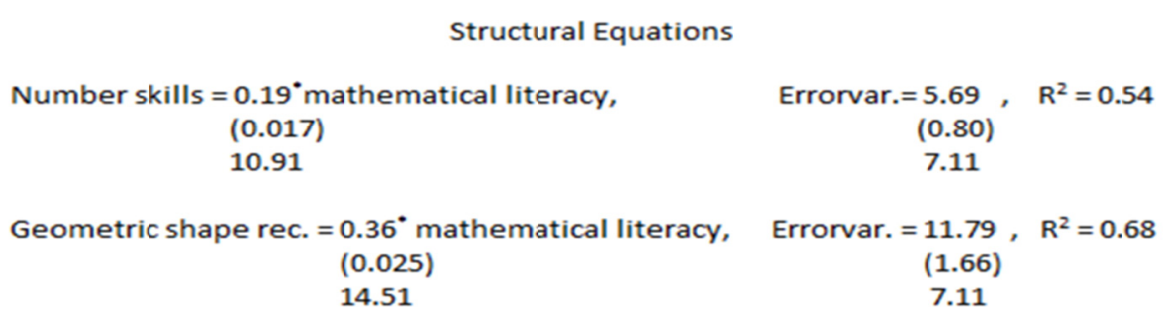

Figure 3. Regression equation for the tested theoretical model

According to the obtained equation, the mathematical literacy self-efficacy of the teachers explain $54 \%$ of the variance in childrens' numerical skills. One unit increase in the mathematical literacy self-efficacy of the teachers would result in a 0.19 point improvement in the childrens' numerical skills. The error value for the equation is calculated as 5.69. In addition, $68 \%$ of the variance in the ability of children to recognize geometric shapes is explained by the mathematical literacy self-efficacy of the teachers. One unit increase in the mathematical literacy self-efficacy of the teachers would result in a 0.36 point improvement in the children's geometric shape recognition. The error value for the equation is computed as 11.79 . The mathematical literacy self-efficacy of the teachers is found to have a relatively greater effect on children's ability to recognize geometric shapes.

\section{Discussion and Recommendations}

Educational theories suggest that one of the most important determinants of the quality of education in a classroom is the teacher (Mashburn et al., 2008; Stipek et al., 2001). Children's ability to acquire mathematical skills such as geometry and number skills is related to the cognitive and emotional traits of teachers, such as self-efficacy. In the literature, teachers' mathematical literacy self-efficacy is characterized as one of the affective characteristics that determine the quality and quantity of mathematical activities (Brown, 2005). Gibson and Dembo (1984) emphasize that teachers with high self-efficacy have higher confidence in their ability to teach and to focus on academic teaching. Other stimuli such as words, actions and social interaction employed by the teacher in daily routines and planned learning processes affect children's attitude towards mathematics and mathematics self-efficacy by passing through their thought and emotional filters. For this reason, the teacher's anxiety or self-confidence regarding mathematics is one of the important factors affecting the mathematical achievement of the individual (Smith, 2009). Past research indicates the existence of a relationship between teacher self-efficacy and children's academic and social skill performance such as reading and mathematics (Bandura, 1993; Goddard, Hoy, \& Woolfolk-Hoy, 2000; Ross, 1992).

According to the first and second sub-objectives of the study, the results indicate that the mathematical literacy self-efficacy level of preschool teachers predict the children's recognition of geometric shapes and their numerical skills. Concepts and skills regarding shapes and numbers begin to take shape from the preschool period in children (Clements, 1998; Clements \& Sarama, 2009) and children's mathematical performance is dependent on the teacher's mathematical competence and self-efficacy concerning application (Chen, McCray, Adams, \& Leow, 2014; Stipek, et al., 2001). Therefore, formal and informal activities of preschool teachers in accordance with the achievements and indicators designated by the Ministry of National Education's Preschool Education Program (2013) provide critical guidance in helping children to acquire these concepts and skills.

The development of geometric thinking in children occurs through the implementation of activities that enable them to learn by doing and living and introducing children to the mathematics inherent in life by touching, drawing and acquiring a perspective about shapes (Clements, 1998). Children construct intuitive and precise information about geometric shapes through objects, situations or events they interact with in everyday activities or games (Clements, 1999; Smith, 2009). Activities where children work with three-dimensional shapes, use a rectangular piece of paper as a paper note and a piece of round paper as a coin, create various geometric shapes on the ground using their bodies, construct figures from materials such as play dough, clay, toothpicks or rope and having conversations about their characteristics, forming new objects with geometric shapes and compiling a book of shapes allow children to gain experience with geometric shapes (Charlesworth \& Radeloff, 1991; Clements, 1998; Kandır et al., 2016). Nevertheless, informal talks and directives of the teacher about informal 
daily life routines in daily life activities such as "Put the square service pads on the square table and the rectangular service pads on the rectangular table. Today we will eat triangular crackers. Put the black blocks in the square box. Put the rectangular blocks in this box. Open the square window, close the rectangular door. There is circle shape on the soup," support the development of children's geometric concepts and skills (Charlesworth \& Radeloff, 1991; Smith, 2009).

Numbers and mathematical operations, another skill predicted by mathematical literacy self-efficacy levels of preschool teachers, involves understanding numbers, improving the grasp of mathematical operations and the ability to calculate quickly. Children's numerical skills develop as they begin to explore numbers in life and communicate with their peers and adults through mathematical thinking (Charlesworth, \& Lind, 2007, Kandir et al., 2016). The development of verbal counting begins verbally around the age of two, improving during the preschool period through as games, singing and poetry as well as dialogues during routine activities such as meals, breakfast, gathering and cleaning. Informative talks from an early age such as emphasizing the numerical print in all areas (e.g. instruments, books, postboxes, license plates, labels, etc.), pointing out that tableware comprise numerous components (e.g. one cup, two spoons, three glasses, etc.), explaining that various parts of our body are of varying numbers, searching for a page in a book, making financial calculations and telling the time and the date help children to focus their attention on numbers (Kandir et al., 2016; Smith, 2009). In addition, teachers should organize their classes so that children can actively participate in mathematical activities, place various materials on geometry and numbers in learning centers, include activities like finger games about shapes and numbers in everyday activities and activities with songs, poems, stories and books into the curriculum and encourage children to participate in these activities, in order to promote children's acquisition of geometric shape and number skills (Clements \& Sarama, 2009; Jackman, 2012).

Using mathematically correct and explicit language when explaining geometric shapes and numbers (Smith, 2009) and opening discussions on mathematical concepts with open ended questions can greatly contribute to children's mathematical knowledge (Klibanoff, Levine, Huttenlocher, Vasilyeva, \& Hedges, 2006). In this process, informal learning is transformed into experiences that can create positive feelings in children (Kandır \& Orçan, 2010) which can encourage them to be more courageous in solving the problems the encounter (Wortham, 2006).

Self-efficacy of the teacher can contribute to increasing the participation of children in class activities and determining the goals of higher education (Ross, 1998 as cited in Holzberger, Philipp, \& Kunter, 2013). In addition, the extensive literature on teachers' self-efficacy shows that teachers with high self-efficacy are more willing to make use of innovations, technologies and teaching methods and techniques (Gellert, 2004; Guskey, 1988; Stein \& Wang, 1988). A positive relationship is found between teachers' self-efficacy and teaching performance (Cheung, 2008; Klassen \& Tze, 2014; Wolters \& Daugherty, 2007). In addition, teachers with high self-efficacy can improve classroom quality for students (Guo, Piasta, Justice, \& Kaderavek, 2010), create a better literacy learning environment and allocate more time to academic activities (Guo, McDonald-Connor, Yang, Roehrig, \& Morrison, 2012). Teachers with mathematical literacy are aware of and understand the role that mathematics plays in the modern world, can transfer mathematics into their daily lives and conduct related applications. Furthermore, they can develop their mathematical thinking skills, use mathematical language, tackle problems with a critical point of view, make rational decisions, analyze and solve problems and think and interpret numerically and spatially. They also have greater self-confidence (Özgen \& Bindak, 2011). Therefore, their ability to create a high-quality classroom environment and learning process is effective in predicting children's geometric shape and numerical skills due to the above-mentioned characteristics related to self-efficacy.

At the same time, teachers with high mathematical literacy self-efficacy can raise individuals with high mathematical literacy self-efficacy and mathematics achievement by positively influencing children's motivation so that they try harder and spend more time to achieve a mathematical task and utilize mathematics in daily life (Bonne, 2012; Rittenhouse, 1998; Zarch \& Kadivar, 2006). According to the results of PISA 2003, the mathematical literacy self-efficacy of 15 -year-old students in Turkey and Finland strongly predicts mathematics achievement (Akarsu, 2009), which indicates that teachers' mathematical literacy self-efficacy can predict children's achievement of geometric shapes and numbers.

High self-efficacy perceptions of teachers were found to be effective in mathematics and reading skills of primary school children (Goddard et al., 2000) and in social skills of eighth and ninth graders (Ross, 1992). These studies show that self-efficacy perception also acts on other academic and social skills related to mathematics and supports the prediction of children's geometric shape recognition and numerical skills. 
The study results show that the teachers' mathematical literacy self-efficacy has a relatively greater influence on the ability to recognize geometric shapes. Studies conducted with preschool teachers and teacher candidates reveal that teachers are lack of knowledge and skills in areas such as geometry teaching and evaluation (Bäckman \& Attorps, 2012; Cantürk-Günhan \& Çetingöz, 2013; Zembat, Sezer, Koçyiğit, \& Balcı, 2014). Moreover, many studies found that preschool children make errors in the recognition of circle, triangle, square, rectangular shapes and distractors (Aslan \& Aktaş Arnas 2007; Clements, Swaminathan, Hannibal \& Sarama 1999; Kesicioğlu, Alisinanoğlu, \& Tuncer, 2011). A mathematically literate individual must have knowledge of basic mathematical operations, numbers, geometry, and trigonometry (OECD, 2003). The ability of teachers with high mathematical literacy self-efficacy levels to pass on their knowledge and skills of geometric shapes to their students might have had a greater effect on the children less skilled in the recognition of geometric shapes.

In conclusion, the study results reveal that the teachers' mathematical literacy self-efficacy level predicted children's ability to recognize geometric shapes and their numerical skills. However, the findings are limited to the students in the sample groups. In this respect, similar studies can be conducted with larger sample groups on the effects of preschool teachers' mathematical literacy self-efficacy levels on children's mathematical skills. Another limitation of the study is the examination of the predictive effect of preschool teachers' mathematical literacy self-efficacy levels on children's recognition of geometric shapes and their numerical skills. The study can be repeated in the future with different variables that may affect children's mathematical skills. In view of the study results, the researchers would like to recommend increasing the number of mathematics courses and elective courses on mathematical literacy in undergraduate education and organizing in-service training seminars to improve the mathematical literacy self-efficacy level of teachers.

\section{References}

Akarsu, S. (2009). Özyeterlik, motivasyon ve PISA 2003 matematik okuryazarlı̆g üzerine uluslararası bir karşılaş̧tırma: Türkiye ve Finlandiya (Unpublished master's thesis). University of Abant İzzet Baysal, Bolu, Turkey.

Akkaya, R., \& Sezgin-Memnun, D. (2012). Öğretmen adaylarının matematiksel okuryazarlığa ilişkin özyeterlik inançlarının çeşitli değişkenler açısından incelenmesi. Dicle Üniversitesi Ziya Gökalp Eğitim Fakültesi Dergisi, 19, 96-111.

Anders, Y., \& Rossbach, H. G. (2015). Preschool teachers' sensitivity to mathematics in children's play: the influence of math-related school experiences, emotional attitudes, and pedagogical beliefs. Journal of Research in Childhood Education, 29(3), 305-322. http://doi.org/10.1080/02568543.2015.1040564

Anders, Y., Grosse, C., Rossbach, H. G., Ebert, S., \& Weinert, S. (2013). Preschool and primary school influences on the development of children's early numeracy skills between the ages of 3 and 7 years in Germany. School Effectiveness and School Improvement: An International Journal of Research, Policy and Practice, 24(2), 195- 211, http://doi.org/10.1080/09243453.2012.749794

Aslan, D. (2004). Anaokuluna devam eden 3-6 yaş grubu çocuklarının temel geometrik şekilleri tanımalarının ve şekilleri ayırt etmede kullandiklarl kriterlerin incelenmesi (Unpublished master's thesis). University of Çukurova, Adana, Turkey.

Aslan, D., \& Aktaş-Arnas, Y. (2007). Three-to six-year-old children's recognition of geometric shapes. International Journal of Early Years Education, 15(1), 83-104. https://doi.org/10.1080/09669760601106646

Bäckman, K., \& Attorps, I. (2012). Teaching mathematics in the preschool context. US-China Education Review $B, 1-16$.

Bandura, A. (1993). Perceived self-efficacy in cognitive development and functioning. Educational Psychologist, 28(2), 117-148. https://doi.org/10.1207/s15326985ep2802_3

Bentler, P. M. (1990). Comparative fit indexes in structural models. Psychological Bulletin, 107(2), 238-246. https://doi.org/10.1037/0033-2909.107.2.238

Bentler, P. M., \& Bonett, D. G. (1980). Significance tests and goodness of fit in the analysis of covariance structures. Psychological Bulletin, 88(3), 588-606. https://doi.org/10.1037/0033-2909.88.3.588

Bonne, L. (2012). The effects of primary students' mathematics self efficacy and beliefs about intelligence on their mathematics achievement: A mixed methods intervention study (Unpublished doctoral dissertation), Victoria University of Wellington, Yeni Zelanda.

Brown, E. T. (2005). The influence of teachers' efficacy and beliefs regarding mathematics instruction in the early childhood classroom. Journal of Early Childhood Teacher Education, 26(3), 239-257. 
https://doi.org/10.1080/10901020500369811

Brown, T. A. (2006). Confirmatory factor analysis for applied research. New York: The Guilford Press.

Byrne, B. M., \& Campbell, T. L. (1999). Cross-cultural comparisons and the presumption of equivalent measurement and theoretical structure: A Look beneath the surface. Journal of Cross-Cultural Psychology, 30(5), 555-574. https://doi.org/10.1177/0022022199030005001

Cantürk-Günhan, B., \& Çetingöz, D. (2013). An examination of preschool prospective teachers subject matter knowledge and pedagogical content knowledge on basic geometric shapes in Turkey. Educational Research and Reviews, 8(3), 93-103. https://doi.org/10.5897/ERR12.168.

Caprara, G. V., Barbaranelli, C., Steca, P., \& Malone, P. S. (2006). Teachers' self-efficacy beliefs as determinants of job satisfaction and students' academic achievement: A study at the school level. Journal of School Psychology, 44(6), 473-490. https://doi.org/10.1016/j.jsp.2006.09.001

Çelik, M. (2014). A study into determining the mathematical development of children attending to kindergartens. Mehmet Akif Ersoy Üniversitesi Eğitim Fakültesi Dergisi, 29(1), 48-68.

Charlesworth, R., \& Lind K. K. (2007). Math \& science for young children (5th ed.). Clifton Park, NY: Thomson Delmar Learning.

Charlesworth, R., \& Radeloff, D. J. (1991). Experiences in math for young children. New York, NY: Delmar Publishers.

Chen, J., McCray, J., Adams, M., \& Leow, C. (2014). A survey study of early childhood teachers' beliefs and confidence about teaching early math. Early Childhood Education Journal, 42(6), 367-377. https://doi.org/10.1007/s10643-013-0619-0

Cheng, E. W. L. (2001). SEM being more effective than multiple regression in parsimonious model testing for management development research. Journal of Management Development, 20(7), 650-667. https://doi.org/10.1108/02621710110400564

Cheung, H. Y. (2008). Teacher efficacy: a comparative study of Hong Kong and Shanghai primary in-service teachers. The Australian Educational Researcher, 35(1), 103-123. https://doi.org/10.1007/BF03216877

Clements, D. H. (1998). Geometric and spatial thinking in young children. Arlington, VA: National Science Foundation. Retrieved from https://eric.ed.gov/?id=ED436232

Clements, D. H., \& Sarama, J. (2009). Learning and teaching early math. New York, NY: Taylor \& Francis Group e-Library.

Clements, D. H., Swaminathan, S., Hannibal, M. \& Sarama, J. (1999). Young children's concepts of shape. Journal for Research in Mathematics Education, 30(2), 192-212. https://doi.org/10.2307/749610

Clements, D.H. (1999). Geometric and spatial thinking in young children. In J. V. Copley (Eds.), Mathematics in the early years (pp.66-79). Reston, VA: National Council of Teachers of Mathematics.

Cohen, L., Manion, L., \& Morrison, K. (2000). Research methods in education. London: Routledge Falmer

Çokluk, Ö., Şekercioğlu, G., \& Büyüköztürk, Ş. (2010). Sosyal bilimler için çok değişkenli istatistik: SPSS ve LISREL uygulamaları. Ankara: Pegem Akademi Yayıncılık.

Czerniak, C. M., \& Chiarelott, L. (1990). Teacher education for effective science instruction: A social cognitive perspective. Journal of Teacher Education, 41(1), 49-58. https://doi.org/10.1177/002248719004100107

Denton, K., \& West, J. (2002). Children's reading and mathematics achievement in kindergarten and first grade. Washington, DC: National Center for Education Statistics. Retrieved from: https://files.eric.ed.gov/fulltext/ED461438.pdf

Gellert, U. (2004). Didactic material confronted with the concept of mathematical literacy. Educational Studies on Mathematics, 55(1-3), 163-179.

Gellert, U., Jablonka, E. \& Keitel, C. (2001). Mathematical literacy and common sense in mathematics education. In B. Atweh, H. Forgasz, \& B. Nebres (Eds.), Sociocultural Research on Mathematics Education An International Perspective (pp.57-73). Mahwah, NJ: Lawrence Erlbaum Associates

Gibson, S., \& Dembo, M. H. (1984). Teacher efficacy: A construct validation. Journal of Educational Psychology, 76(4), 569-582. https://doi.org/10.1037/0022-0663.76.4.569

Goddard, R. D., Hoy, W. K., \& Woolfolk-Hoy, A. (2000). Collective teacher efficacy: its meaning, measure, and 
effect on student achievement. American Education Research Journal, 37(2), 479-507. https://doi.org/10.2307/1163531

Guo, Y., McDonald-Connor, C., Yang, Y., Roehrig, A. D., \& Morrison, F. J. (2012). The effects of teacher qualification, teacher self-efficacy, and classroom practices on fifth graders' literacy outcomes. The Elementary School Journal, 113(1), 3-24. https://doi.org/10.1086/665816

Guo, Y., Piasta, S. B., Justice, L. M., \& Kaderavek, J. N. (2010). Relations among preschool teachers' self-efficacy, classroom quality, and children's language and literacy gains. Teaching and Teacher Education, 26(4), 1094-1103. https://doi.org/10.1016/j.tate.2009.11.005

Guskey, T. (1988). Teacher efficacy, self-concept, and attitudes toward the implementation of instructional innovations. Teaching and Teacher Education, 4(1), 63-69. https://doi.org/10.1016/0742-051X(88)90025-X

Holzberger, D., Philipp, A., \& Kunter, M. (2013). How teachers' self efficacy is related to instructional quality: A longitudinal analysis. Journal of Educational Psychology, 105(3), 774-786. https://doi.org/10.1037/a0032198

Jackman, H. L. (2012). Early education curriculum a child's connection to the world (5th ed). USA: Wadsworth, Cengage Learning.

Jöreskog, K. G., \& Sörbom, D. (1993). LISREL 8: User's guide. Chicago: Scientific Software.

Kandır, A., \& Orçan, M. (2010). Okul öncesi dönemde matematik eğitimi. İstanbul: Morpa Yayıncılık.

Kandır, A., Can-Yaşar, M., Yazıcı, E., Türkoğlu, D., \& Yaman-Baydar, I. (2016). Erken çocuklukta matematik. İstanbul: Morpa Yayınevi.

Kaufman, A. S., \& Kaufman N. L. (1993). K-SEALS Kaufman Survey of Early Academic and Language Skills: Manual. USA: Pearson Assesments.

Kesicioğlu, O, S., Alisinaoğlu, F., \& Tuncer, A. T. (2011). Okul öncesi dönem çocukların geometrik şekilleri tanıma düzeylerinin incelenmesi. İlköğretim Online, 10(3), 1093-1111.

Klassen, R. M., \& Tze, V. M. C. (2014). Teachers' self efficacy, personality, and teaching effectiveness: A meta-analysis. Educational Research Review, 12, 59-76. https://doi.org/10.1016/j.edurev.2014.06.001

Klibanoff, R. S., Levine, S. C., Huttenlocher, J., Vasilyeva, M., \& Hedges, L. V. (2006). Preschool children's mathematical knowledge: The effect of teacher "math talk". Developmental psychology, 42(1), 59-69. https://doi.org/10.1037/0012-1649.42.1.59

Kline, R. B. (2011). Principles and practice of structural equation modeling (3rd ed.). New York, NY: The Guilford Press.

Marsh, H. W., \& Hocevar, D. (1985). Application of confirmatory factor analysis to the study of self-concept. First-and higher order factor models and their invariance across groups. Psychological Bulletin, 97(3), 562-582. https://doi.org/10.1037/0033-2909.97.3.562

Mashburn, A. J., Pianta, R. C., Barbarin, O. A., Bryant, D., Hamre, B. K., Downer, J. T., ... Howes, C. (2008). Measures of classroom quality in prekindergarten and children's development of academic, language, and social skills. Child Development, 79(3), 732-749. https://doi.org/10.1111/j.1467-8624.2008.01154.x

McMillan, J. H., \& Schumacher, S. (2006). Research in education: Evidence-based inquiry. Boston: Pearson Education

Milli Eğitim Bakanlığı [MEB]. (2013). Okul öncesi eğitim programı. Ankara: Milli Eğitim Bakanlı̆̆ı.

National Council of Teachers of Mathematics [NCTM]. (2000). Executive summary principles and standarts for school mathematics. The United States and Canada: National Council of Teachers of Mathematics. (NCTM).Retrievedfrom:https://www.nctm.org/uploadedFiles/Standards_and_Positions/PSSM_ExecutiveSu mmary.pdf

Organisation for Economic Co-Operation and Development [OECD], (2003). The PISA 2003 assessment framework-mathematics, reading, science and problem solving knowledge and skills. Paris: Organisation for Economic Co-Operation and Development [OECD]. Retrieved from http://www.oecd.org/education/school/programmeforinternationalstudentassessmentpisa/33694881.pdf

Özgen, K., \& Bindak, R. (2008). Matematik okuryazarlığı öz-yeterlik ölçeğinin geliştirilmesi. Kastamonu Eğitim Dergisi, 16(2), 517-528. 
Özgen, K., \& Bindak, R. (2011). Lise öğrencilerinin matematik okuryazarlı̆̆ına yönelik öz yeterlik inançlarının belirlenmesi. Kuram ve Uygulamada Eğitim Bilimleri, 11(2), 1073-1089.

Pajares, F., \& Miller, M. D. (1994). The role of self-efficacy and self-concept beliefs in mathematical problem solving: A path analysis. Journal of Educational Psychology, 86(2), 193-203. https://doi.org/10.1037/0022-0663.86.2.193

Rittenhouse, P. S. (1998). The teacher's role in mathematical conversation: Stepping in and stepping out. In M. Lampert, \& M. L. Blunk (Eds.), Talking mathematics in school: Studies of teaching and learning (Learning in doing) (pp.163-189) Port Chester, NY: Cambridge University Press

Ross, J. A. (1992). Teacher efficacy and the effects of coaching on student achievement. Canadian Journal of Education, 17(1), 51-65. https://doi.org/10.2307/1495395

Schermelleh-Engel, K., Moosbrugger, H., \& Müller, H. (2003). Evaluating the fit of structural equation models: Tests of significance and descriptive goodness-of-fit measures. Methods of Psychological Research Online, $8(2), 23-74$.

Smith, S.S. (2009). Erken çocuklukta matematik. Ankara: Eğiten Kitap.

Sönmez, V., \& Alacapınar, F. G. (2013). Örneklendirilmiş bilimsel araştırma yöntemleri. Ankara: Anı Yayıncılık

Stein, M. K., \& Wang, M. C. (1988). Teacher development and school improvement: The process of teacher change. Teaching and Teacher Education, 4(2), 171-187. https://doi.org/10.1016/0742-051X(88)90016-9

Stipek, D. J., Givvin, K. B., Salmon, J. M., \& MacGyvers, V. L. (2001). Teachers' beliefs and practices related to mathematics instruction. Teaching and Teacher Education, 17(2), 213-226. https://doi.org/10.1016/S0742-051X(00)00052-4

Thompson, D. R., \& Chappell, M. F. (2007). Communication and representation as elements in mathematical literacy. Reading \& Writing Quarterly, 23(2), 179-196. https://doi.org/10.1080/10573560601158495

Thornton, J. S., Crim, C. L., \& Hawkins, J. (2009). The impact of an ongoing professional development program on prekindergarten teachers' mathematics practices. Journal Early Childhood Teacher Education, 30(2), 150-161. https://doi.org/10.1080/10901020902885745

Tschannen-Moran, M., \& Woolfolk-Hoy, A. (2001). Teacher efficacy: Capturing an elusive construct. Teaching and Teacher Education, 17(7), 783-805. https://doi.org/10.1016/S0742-051X(01)00036-1

Uyanık, Ö., \& Kandır, A. (2014). Kaufman Erken Akademik ve Dil Becerileri Araştırma Testi'nin 61-72 aylık Türk çocuklarına uyarlanması. Kuram ve Uygulamada Eğitim Bilimleri, 14(2), 669-692. https://doi.org/10.12738/estp.2014.2.1682

Wetson, R., \& Gore Jr., P. A. (2006). A brief guide to structural equation model. The Counseling Psychologist, 34(5), 719-751. https://doi.org/10.1177/0011000006286345

Wolters, C. A., \& Daugherty, S. G. (2007). Goal structures and teachers' sense of efficacy: their relation and association to teaching experience and academic level. Journal of Educational Psychology, 99(1), 181-193. https://doi.org/10.1037/0022-0663.99.1.181

Wortham, C. S. (2006). Early childhood curriculum, developmental bases for learning and teaching (4th ed.). New Jersey: Pearson/Merrill/Prentice Hall.

Yıldırım, A., \& Şimşek, H. (2016). Sosyal bilimlerde nitel araştırma yöntemleri (Genişletilmiş 10. baskl). Ankara: Seçkin Yayıncılık.

Yore, L. D., Pimm, D., \& Tuan, H. L. (2007). The literacy component of mathematical and scientific literacy. International Journal of Science and Mathematics Education, 5(4), 559-589. https://doi.org/10.1007/s10763-007-9089-4

Zarch, M. K., \& Kadivar, P. (2006, May). The role of mathematics self-efficacy and mathematics ability in the structural model of mathematics performance. Proceedings of the 9th WSEAS International Conference on Applied Mathematics, Istanbul, Turkey, May 27-29, 2006 (pp. 242-249). Retrieved from http://www.wseas.us/e-library/conferences/2006istanbul/papers/522-220.pdf

Zembat, R., Sezer, T., Koçyiğit, S., \& Balci, A. (2014). Preschool Teachers Views on Geometry. In M. Yasar, O. Ozgun, \& J. Galbraith (Eds.), Contemporary perspectives and research on early childhood education (pp. 153-164). Newcastle, UK: Cambridge Scholar Publishing.

Zopluoğlu, C. (2014). Uluslararası öğrenci değerlendirme programı (PISA) 2012 Türkiye Değerlendirmesi: 
Matematik. Retrieved from https://www.academia.edu/6057970/Uluslararas\%C4\%B1_\%C3\%96\%C4\%9 Frenci_De $\%$ C4\%9Ferlendirme_Program\%C4\%B1_PISA_2012_T\%C3\%BCrkiye_De $\%$ C $4 \% 9$ Ferlendirmes i_Matematik

\section{Copyrights}

Copyright for this article is retained by the author(s), with first publication rights granted to the journal.

This is an open-access article distributed under the terms and conditions of the Creative Commons Attribution license (http://creativecommons.org/licenses/by/4.0/). 